\title{
RASIONALISASI WUJUD TUHAN
}

\author{
Akhmad Ali Said \\ 4ssaid.aly@gmail.com \\ Dosen Ilmu Tasawuf IAI Pangeran Diponegoro Nganjuk
}

\begin{abstract}
Abstrak
Di dunia ini banyak orang yang tidak percaya akan wujud Tuhan (atheis). Hal itu di dasarkan pada paham empirisme bahwa sesuatu itu dianggap ada kalau bisa diindera. Artikel ini akan membahas tentang rasionaliasi wujud Tuhan dan lebih jauh tentang kebenaran bertuhan, sebab ada banyak faham yang bermaca-macam tentang Tuhan. Kesimpulan artikel ini adalah keyakinan bertuhan dapat dibenarkan kalau lulus uji. Batu uji ketuhanan itu adalah kekal, monotheis, tan rīh serta bebas relativitas. Sedangkan wujud Tuhan dapat diketahui melalui rasionalisasi terhadap jagad raya, bukan empirisasi terhadap wujud Tuhan itu sendiri.
\end{abstract}

\section{Kata kunci: tuban, taubid.}

\section{Latar Belakang}

Pada tanggal 29 November 2012 "On The Sport Trans 7" menayangkan 7 orang yang meninggal dunia karena ucapannya yang menghina Tuhan, entah disengaja atau tidak, namun buktinya ke tujuh orang tersebut mengalami nasib yang tragis.

Pertama, calon presiden Brazil bernama Tancredo Neves, yang menyatakan bahwa "Jika saya mendapatkan 500.000 suara, maka tidak akan ada orang yang dapat melengserkan saya, bahkan Tuhan sekalipun". Ternyata hasil pemilu memang sesuai dengan apa yang diharapakan oleh calon tersebut, namun sayangnya sehari sebelum ia dilantik sebagai presiden baru, ia mengidap penyakit sehingga meninggal. 
Kedua, John Lenon salah seorang penyanyi yang sombong akan ketenarannya sampai-sampai ia mengatakan bahwa ketenarannya melebihi Tuhan. Namun sayang, dia meninggal karena di tembak oleh penggemarnya sendiri.

Ketiga, Thomas Endrew. Ia adalah seorang perancang kapal Titanic yang terkenal dengan desain yang sangat mewah dan besar pada saat itu, sehingga ada sebagian orang yang bertanya tentang kapal buatannya "seberapa amankah kapal buatanmu ini"? Ia menjawab "Bahkan Tuhanpun tidak akan dapat menenggelamkannya". Namun kenyataannya setelah berlayar beberapa hari, kapal Titanic tersebut menabrak karang es sehingga tenggelam dan menelan korban jiwa sangat banyak.

Keempat, Marilyn Monroe. Ia adalah seorang artis Amerika di tahun 90'an yang sangat terkenal pada masanya. Namun sayang ia pernah menyatakan bahwa ia tidak butuh Tuhan. Seminggu kemudian ia ditemukan tewas di apartemennya.

Kelima Cazuza. Ia adalah seorang aktris yang memiliki album dengan angka penjualan yang sangat fantastis hingga melebihi 5.000 copy. Karena ketenarnya tersebut ia sempat mengatakan bahwa "ketenaranku melebihi ketenaran Tuhan". Namun tidak berselang lama dari apa yang diucapaknnya itu, ada fans yang menembaknya sehingga ia meninggal dunia.

Keenam, ada seorang remaja di Brazil yang sedang menjemput teman gadisnya, sementara ibu gadis tersebut khawatir dengan kepergian anaknya, lalu ibunya mengatakan "Tuhan bersamamu" lalu gadis tersebut menjawab "Tuhan boleh bersama kita asalakan bertempat di bagasi" sentak setelah beberapa saat dalam perjalanan dua remaja tersebut mengalami kecelakaan hingga mobil yang ditumpanginya hancur lebur kecuali bagasi.

Ketujuh, Bon Scott adalah seorang mantan vocalis band AC/DC yang pernah berkata secara mengejutkan. Pada salah satu albumnya di tahun 1979 ia menyatakan 'Jangan hentikan saya, saya sedang ayik jalan 
ke neraka'. Akhirnya tidak lama kemudian, pada bulan Februari tahun 1980, ia meninggal dunia karena menenggak muntahannya sendiri. ${ }^{1}$

\section{Batu Uji Pada Tuhan}

Di dunia ini ada banyak agama yang meyakini terhadap Tuhannya masing-masing, semua di anggap benar menurut keyakinan masing-masing. namun perlu diketahui bahwa keyakinan tersebut bukan lekas menegasikan adanya ujian terhadap sebuah keyakinan. Manusia tahu bahwa segala sesuatu itu dianggap baik jika ia telah terbukti lulus dalam ujiannya. Contoh dalam hal ini cukup banyak. Anak SD dianggap baik jika ia mampu lulus dari ujiannya dan melanjutkan kembali ke jenjang atasnya. Anak SMP dianggap baik jika ia mampu lulus dari ujiannya, begitu juga seterusnya sampai di perguruan tinggi.

Orang yang mampu lulus berarti ia adalah orang yang diakui kualitasnya. Bigitu juga dalam masalah Tuhan. Sekian banyak agama yang ada di diunia ini mengklaim bahwa Tuhannya-lah yang benar dan yang dipuja oleh umat lain adalah salah, atau pemahaman terhadap tuhan itu sendiri yang salah? Untuk itu disini penulis akan mencantumkan beberapa batu uji terhadap klaim-klaim ketuhanan yang diasumsikan oleh semua orang.

Langkah yang penulis tempuh adalah: pertama, terlebih dahulu kita harus memiliki sikap netral. Artinya jangan menoleh terhadap suatu agama tertentu untuk mendapatkan hasil secara obyektif. Kedua, tabiat manusia. Ketiga, bebas relativitas.

1. Netralitas keyakinan

Netralitas adalah langkah awal untuk menguji klaimklaim ketuhanan yang menjadi keyakinan semua umat beragama. Netralitas keyakinan adalah menghilangkan terlebih dahulu apa yang ada di dalam pemikiran seseorang tentang keyakinan ketuhanan. Langkah ini dilakukan agar mendapatkan hasil seobyektif mungkin. Dalam hal ini penulis mengajukan

\footnotetext{
1 Saduran dari beberapa sumber: https://www.solopos.com, http://cumantujuh.blogspot.com/2013/07/7-orang-meninggal-tak-wajarakibat.html?m=1.
} 
beberapa langkah untuk menilai keakuratan suatu faham keagamaan tentang Tuhan dengan beberapa tahap yaitu pertama, tentang tabiat. Kedua, relativitas. Ketiga non-otomatik dan keempat teori the most. Keempat hal ini merupakan perkara yang tidak dimiliki oleh faham keagamaan manapun. Karena ia mandiri dari keberpihakan terhadap faham ketuhanan satu agama tertentu.

2. Tabiat

Tabiat adalah pikiran bawaan manusia. Andaikata seseorang tidak mendengar suatu berita, maka ke mana keyakinan orang tersebut. keyakina genuine itulah yang disebut dengan tabiat. Dalam teori ini seseorang terlebih dahulu harus melepaskan dogma-dogma ketuhanan yang ada dalam benaknya. Tujuannya adalah agar dapat memasuki nuansa pemahaman yang baru dalam menilai objektivitas sebuah paham. Kelompok yang terlibat di sini bukanlah dari kelompok agamawan, akan tetapi dari kelompok yang murni belum pernah tersentuh oleh faham-faham keagamaan, oleh sebab itu faham mereka terhadap Tuhan dapat dikatakan sebagi faham yang alami secara tabiat, belum terkontaminasi dengan doktrin-diktrin agama manapun.

Dalam masalah ini penulis mengemukakan faham orang-orang yang jauh dari peradaban atau dapat dikatakan sebagai orang primitif. Jangan dikira orang yang belum pernah mendengar satu agamapun, ia dikatakan tidak memiliki keyakinan tentang Tuhan. Justru sebaliknya, meskipun mereka tidak pernah mendengar suatu agama, namun ia juga memiliki kayakinan terhadap adanya Tuhan. Hal tersebut dapat dilihat dari suku-suku yang berada di Afrika Selatan yang dapat dikatakan tidak tersentuh oleh agama manapun, akan tetapi mereka juga memiliki keyakinan tentang Tuhan.

Di Afrika ada sebuah suku primitif yang bernama Mao Mao. Suku ini memiliki keyakinan terhadap Tuhan Yang Maha Esa yang sangat kuat. Merena memberi nama Tuhannya sebagai "Mogabi". Mogabi dalam pandangan mereka adalah Tuhan 
tidak sama dengan yang lainnya, tidak beranak dan tidak dipernakkan. Ia tidak dapat dilihat oleh kasat mata, akan tetapi Ia dapat diketahui melalui ciptaannya. Pemberi rizki, hujan, anugerah dan sebaginya, kilat adalah pedangnya dan guntur adalah langkah kakinya. ${ }^{2}$

Selain suku Mao Mao, ada juga suku Niam Niam yang berkeyakinan bahwa Tuhan itu adalah Esa, ia menyebut Tuhannya dengan sebutan Maboli. Segala yang terjadi di jagad raya ini adalah karena keadilan dan kehendaknya. Ada juga suku Danka yang berkeyakinan bahwa Tuhan itu satu yang bernama Nialak, ia adalah tuhan yang berada di langit dan yang paling mulia. ${ }^{3}$

Sejarah mencatat bahwa suku-suku yang berada di Afrika ini tidak memiliki keyakinan terhadap penyembahan kepada patung atau yang sesamnaya, mereka cukup meyakini adanya tuhan tersebut. Ketika ditanya mengapa mereka tidak membuat patung-patung (gambaran) Tuhan untuk disembah? Mereka menjawab bahwa "bagaimana mungkin kami membuat Tuhan yang tidak sama dengan sesuatu apapun, Ia tidak sama dengan mahluknya". Namun sebagian dari mereka berubah keyakian menjadi penyembah patung ketika datang orang-orang Amerika, mereka tuduk kepada patung-patung (Yesus, Maria dll)..$^{5}$

Selain suku-suku yang disebutkan di atas, ada juga kaum Zulu yang memiliki sebutan kepada Tuhan yaitu "Umvellinggang" kata ini sepadan dengan kata "Allah al-Ghāni" dalam bahwa Arab yang memiliki arti Allah Maha Kaya. Jika kaum Zulu ditanya tentang maksud dari "Umvalinggang"

${ }^{2}$ Mahmudin, Menemukan Kebenaran Islam. Yogyakarta: Gava Media, 2006, 231.

3 Ibid, 231.

4 Pernyataan ini sangat mirip dengan konsep teologi di dalam Islam, yaitu di dalam surah al-Shūra [42]:11, lays kamithlh shay' (tiada satupun yang serupa dengan-Nya). Lihat, Departemen Agama Republik Indonesia, al-Qur'an dan Terjemahnya. Surabaya: Pustaka Assalam, 2010, 694.

5 Ibid, 232. 
mereka akan menjawab dengan "Huwa umnimzani! Uyena, Umoya oingowele, akarali yena, futh! Akaralwanga, futhi, akukholutho olu fana naye" kata-kata ini bila diterjemahkan menjadi "Oh, Tuan, dia adalah jiwa yang murni dan suci, di tidak beranak dan tidak diperanakkan, dan tidak ada yang menyerupainya."6

Dari beberapa pemaparan tentang faham ketuhanan yang dimiliki oleh orang-orang primitif yang tidak mengenal agama ini dapat kita simpulkan bahwa Tuhan dalam pandangan mereka adalah Esa, Maha Kuasa, tidak sama dengan lainnya, tidak beranak dan tidak pula diperanakkan. Kesimpulan inilah yang nantinya akan dijadikan sebagi batu uji bagi faham ketuhanan yang ada pada agama-agama. Karena pada dasarnya faham ini adalah faham yang murni belum tercampuri oleh dogma dan ajaran agama manapun.

3. Bebas Relativitas

Teori ini dimunculkan oleh Albert Einstein ${ }^{7}$ yang memiliki pandangan bahwa segala sesuatu itu relatif dan terbatas jika masing di dalam empat dimensi, yaitu: waktu, ruang, tempat, daya dan guna. Segala sesuatu yang masih berada dalam empat dimensi ini, maka ia dikatakan sebagi hawadis (sesuatu yang baru, ciptaan Tuhan) karena Tuhan di luar keempat dimensi ini. Oleh karena itu syarat dinamakan Tuhan harus mutlak $^{8}$ (tidak terikat oleh keempat dimensi tadi). Bila ia ada dan menghilang, maka ia bukan Tuhan.

Bila teori relativitas ini diterapkan pada teologi Kristen?, maka akan terjadi keganjilan pada ketuhanan Yesus. Sekarang

${ }^{6}$ Mahmudin, Menemukan Kebenaran Islam. Yogyakarta: Gava Media, 2006, 230.

7 Albert Einstein adalah fisikawan asal Jerman yang hidup pada tahun 1879-1955.

8 Mahmudin, 241.

9 Pada hakikatnya nama Kristen bukanlah kata yang diberikan oleh Yesus. Akan tetapi diberikan oleh para rasul (sahabat) Yesus. Hal ini didasarkan pada kitab Injil yang tidak menyebutkan sama sekali nama Kristen. Akan tetapi pada Kisah Para Rasul 11:25-26 dinyatakan bahwa: Lalu pergilah Barnabas ke Tarsus untuk mencari Saulus; dan setelah bertemu dengan dia, ia membawanya ke Antiokhia. Mereka tinggal bersama- 
Spiritualis, vol. 4, no. 2, September 2018|159

penulis akan mencoba menerapkan 'teori-teori' tersebut untuk menguji ketuhanan yang ada di dalam Kristen.

1. Abadi

Sikap netral ini harus terdapat dalam setiap keyakinan umat beragama, jika tidak diterapkan kepada semuanya maka menjadi tidak adil. Untuk itu semua keyakinan tentang Tuhan harus diuji dengan cara yang sama pula. Itu artinya semua umat beragama harus memiliki kriteria ini, yaitu Tuhan abadi. Karena jika Tuhan itu tidak abadi maka bagaimana kehidupan di dunia ini, siapa yang akan mengendalikannya?

Kita melihat doktrin agama Kristen bahwa Tuhan itu ada tiga, Bapak, Anak dan Roh Kudus. maka di sini kita akan melihat kecacatan pada sisi Yesus. Mengapa demikian karena ia adalah manusia yang mengalami kematian. Tidak mungkin ia memiliki dua tabiat secara bersamaan, baik tabiat manusia maupun tabiat Tuhan. Yesus meninggal "di tiang salib" dalam kepercayaan Kristen. Itu artinya ia tidak lagi abadi dan tidak layak untuk menjadi Tuhan. Selain itu, penetapan ketuhanan Yesus juga terkait oleh ruang dan waktu. Sejarah mencatat bahwa Yesus murni diangkat sebagai Tuhan pada tahun 325 Masehi saat konsili di Nikea.

Batu uji keyakinan yang mempertuhankan manusia ini berlaku untuk semua faham, bukan hanya Kristen. Sebab semua yang menuhankan manusia itu memiliki keterbatasan ruang dan

sama jamaat itu satu tahun lamanya, sambil mengajar banyak orang. Di Antiokhialah murid-murid itu untuk pertama kalinya disebut Kristen. Lembaga Alkitab Indonesia, Alkitab Terjemahan Baru (Jakarta: LAI, 1994), 68. Meskipun demikian, banyak klaim menyatakan bahwa agama ini diusung oleh Yesus (Isa as.) Yesus adalah seorang pemuda dari Isra'il yang lahir di Nazaret, ia adalah putera dari seorang wanita yang tidak disentuh oleh laki-laki (berhubungan seksual) dalam hal ini antara agama Islam dan Kristen sepakat bahwa Yesus adalah anak seorang wanita yang lahir tanpa melakukan hubungan seks. Sementara dalam Kristen ia dianggap sebagai Tuhan anak dan Roh Kudus juga sebagai Tuhan dan juga Tuhan Bapak. Artinya dalam Kristen kayakinan terhadap Tuhan itu adalah trinitas (mengakui adanya tiga tuhan) atau tritunggal (tiga dalam satu). Yesus (Isa as) memiliki kitab suci yang bernama Injil. 
waktu. Itu artinya, ia ada dalam satu waktu dan tiada di waktu yang lain. Ia ada di suatu tempat dan tidak ada di tempat yang lain. Tuhan, juga bukan benda yang bisa diciptakan atau dihancurkan. Dengan demikian ia tidak abadi dan tidak dapat dikategorikan sebagai Tuhan.

Dalam hal ini, nabi Ibrahim meiliki cerita yang cukup menarik. Ketika mereka menannyakan kepada Ibrahim tentang siapa yang melakukan perusakan terhadap berhala-berhala mereka, maka Ibrahim menjawab, "Itulah dia yang paling besar. Kalau tidak percaya, maka tanyakanlah kepadanya.” Sungguh suatu jawaban yang sangat logis untuk menumbangkan argumentasi mereka tentang apa yang mereka sembah saat itu, yaitu berhala. Argumentasi yang dibangun oleh Ibrahim tentang siapa Tuhan dan siapa berhala akan nampak jelas dengan ayat ini, yaitu bagi mereka yang hendak mencari bukti siapa yang melakukan perusakan terhadap berhala-berhala tadi, maka mereka diperintahkan oleh Ibrahim agar menannyakan kepada yang paling besar.

Dengan perintah itu, secara otomatis mereka akan memiliki jawaban "Mana mungkin dia bisa bicara." Nah, jawaban itulah yang diinginkan oleh Ibrahim agar mereka sendiri dapat menyimpulkan bahwa apa yang selama ini mereka sembah adalah tidak mengerti apa-apa dan tidak memberikan madharat maupun manfaat. Justru dengan menyembah kepada berhala ini menunjukkan bahwa hal itu merendahkan diri mereka sendiri yang bisa berfikir dan menalar bahwa berhala adalah buatan manusia yang kemudian disembahnya sendiri.

\section{Pengembaraan Para Pencari Tuhan}

Dalam perkembangan filsafat ilmu, ada sebuah faham "materealis" yang berangggapan bahwa segala sesuatu itu dianggap ada jika ia berbentuk materi, ${ }^{10}$ tak terkecuali dengan urusan Tuhan. Faham materialis ini dikembangkan di dunia

10 Andi Mu'awiyah Ramli, Peta Pemikiran Karl Marx: Materialisme Dialektis dan Materialisme Historis. Yogyakarta: LKiS, 2000, 19-20. 
Barat dan banyak membawa kemajuan dari segi ilmu pengetahuan dan teknologi karena mereka condong untuk bersikap positif terhadap segala sesuatu yang mendorong dunia Barat menjadi negara yang maju dan memegang kendali peradaban dunia. Namun di sisi lain, perkembangan filsafat materialisme ini memunculkan gagasan baru tentang ke-alfa-an Tuhan karena segala hal dianggap ada jika ia dapat dilihat. Oleh sebab itu, tidak jarang masyarakat Barat yang menganut faham materilis ini menjadi seorang atheis (tidak meyakini adanya Tuhan). Jika Tuhan dapat dilihat maka ia akan percaya, dan apabila tidak dapat dilihat, maka ia tidak akan percaya.

Fenomena tentang tuntutan manusia untuk dapat melihat Tuhan sebenarnya telah ada jauh sebelum ilmu pengetahuan modern, hal tersebut dikisahkan oleh al-Qur'an surat al-An'am (6) ayat 74-79, memalui pengembaraan nabi Ibrahim as.

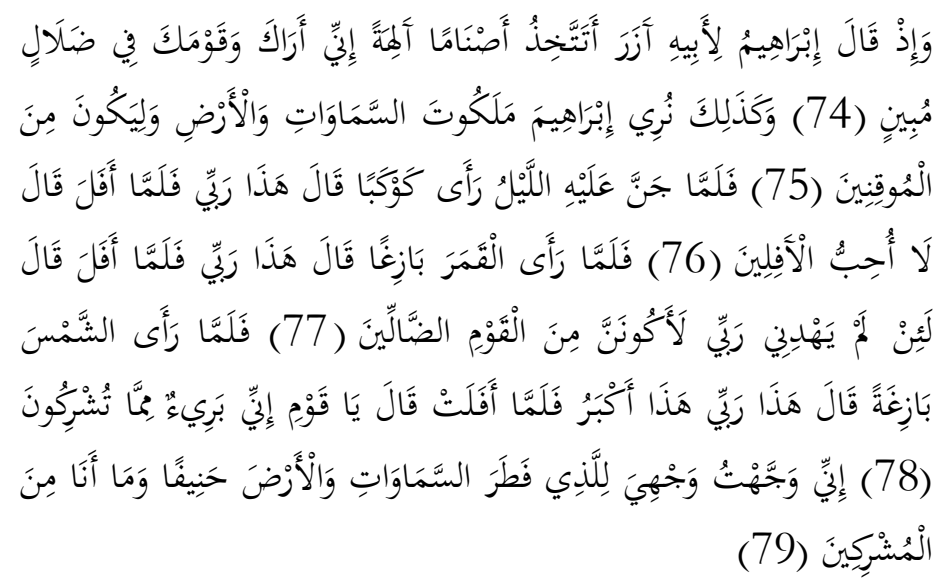

Dan (ingatlah) diwaktu Ibrahim Berkata kepada bapaknya, Azar, "Pantaskah kamu menjadikan berhalaberhala sebagai tuhan-tuhan? Sesungguhnya aku melihat kamu dan kaummu dalam kesesatan yang nyata." 75 . Dan demikianlah Kami perlihatkan kepada Ibrahim tanda-tanda keagungan (Kami yang terdapat) di langit 
dan bumi dan (Kami memperlihatkannya) agar dia termasuk orang yang yakin. 76. Ketika malam telah gelap, dia melihat sebuah bintang (lalu) dia berkata: "Inilah Tuhanku", tetapi tatkala bintang itu tenggelam dia berkata: "Saya tidak suka kepada yang tenggelam." 77. Kemudian tatkala dia melihat bulan terbit dia berkata: "Inilah Tuhanku". tetapi setelah bulan itu terbenam, dia berkata: "Sesungguhnya jika Tuhanku tidak memberi petunjuk kepadaku, pastilah aku termasuk orang yang sesat." 78. Kemudian tatkala ia melihat matahari terbit, dia berkata: "Inilah Tuhanku, ini yang lebih besar". Maka tatkala matahari itu terbenam, dia berkata: "Hai kaumku, sesungguhnya aku berlepas diri dari apa yang kamu persekutukan. 79. Sesungguhnya aku menghadapkan diriku kepada Rabb yang menciptakan langit dan bumi, dengan cenderung kepada agama yang benar, dan aku bukanlah termasuk orang-orang yang mempersekutukan Tuhan.

Kisah pengembaraan nabi Ibrahim di atas dapat dijadikan rujukan sebagai refleksi tentang adanya berbagai keyakinan yang ada pada saat ini bahwa bertuhan kepada selain Allah adalah sebuah keraguan dan kesesatan. Walaupun nabi Ibrahim adalah seorang anak dari tukang patung, namun dalam urusan bertuhan, ia tidak lekas mengikuti apa yang ada pada keluarganya, akan tetapi ia akan menguji terlebih dahulu tuhantuhan yang diklaim oleh keluarganya sendiri. Nabi Ibrahim mengkritisi sikap para pemuja berhala - meskipun ayahnya sendiri - dengan berbagai argumen bahwa: berhala adalah buatan manusia dan ia diam tanpa memiliki kekuatan apapun, untuk itu wajar apabila nabi Ibrahim menannyakan kepatutan tentang penyembahan berhala tersebu?

Ketika malam tiba dan ia melihat bintang, maka ia menduga bahwa mungkin inilah tuhan? Namun tidak berlalu lama, ketikan pagi sudah datang maka bintang itupun 
menghilang, dan ia sungguh tidak mempercayai jika tuhan harus menghilang. Pada saat ia melihat bulan juga menduga yang demikian, namun seiring hilangnya malam maka iapun juga memiliki prasangka yang sama terhadap bintang, bahwa tidak mungkin tuhan ada disuatu waktu dan kemudian menghilang diwaktu yang lain. Begitu pula yang terjadi ketika nabi Ibrahim melihat matahari yang besar terbit, ia juga mengira bahwa itu adalah tuhan, namun lagi-lagi prasangka itu tidaklah benar, karena tidak mungkin tuhan menghilang disuatu waktu.

Penyembahan terhadap berhala, matahari, bulan, bintang, itu semua juga banyak terjadi meskipun di dunia modern pada saat ini, namun kita dapat mengambil pelajaran yang sangat berharga dari pengembaraan itu dan mencontoh nabi Ibrahim yang menyimpulkan bahwa itu semua adalah mahluk, bukan Khäliq untuk itu nabi Ibrahim menyatakan ketundukannya kepada sang Khäliq, Tuhan yang menciptakan itu semua, yang selalu ada, tidak sirna dan tetap abadi.

Kisah nabi Mūsa juga tidak jauh berbeda dengan umat nabi Ibrähïm. Al-Qur'an menjelaskan dalam surat al-Baqarah ayat 55:

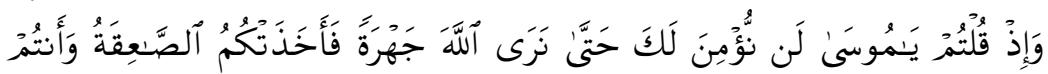

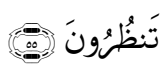

Dan (ingatlah), ketika kamu berkata: "Hai Musa, kami tidak akan beriman kepadamu sebelum kami melihat Allah dengan terang, karena itu kamu disambar halilintar, sedang kamu menyaksikannya".

Ayat ini dengan tegas menyinggung kaum atheis bahwa - bagaimanapun - Tuhan tidak dapat dilihat. Lalu bagaimana cara manusia melihat Tuhan? Orang-orang yang ternama dalam sejarah umat Islam juga memiliki pemahaman yang sangat baik didalam menjelaskan keberadaan Tuhan, suatu saat Ali bin Abi Talib ditanya oleh seorang sahabatnya Zi'lib al-Yamani "apakah anda pernah melihat Tuhan?" beliau menjawab "bagaimana saya 
menyembah yang tidak pernah saya lihat?" lalu sahabat tersebut bertanya lagi, "bagaimana anda melihatnya"? "Dia tidak bisa dilihat oleh kasat mata, akan tetapi dapat dilihat dengan mata hati dengan hakikat keimanan." "11

Sejak dahulu hingga sekarang memang manusia di dunia ini menginginkan melihat Tuhan, namun demikian manusia tidak akan mampu melihatnya, bahkan orang-orang pilihan sekalipun. Nabi Musa as. pernah berdoa agar Tuhan menampakkan diri-Nya, lalu Allah berfirman dalam surah alA’rāf [17]: 143

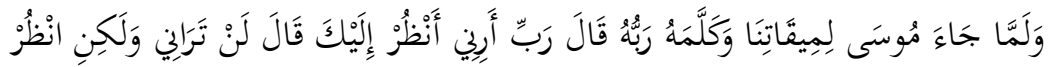

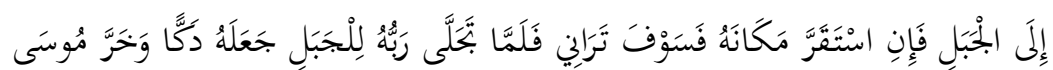

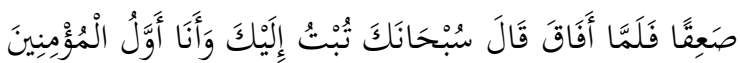

Dan tatkala Musa datang untuk (munajat dengan Kami) pada waktu yang telah kami tentukan dan Tuhan telah berfirman (langsung) kepadanya, berkatalah Musa: "Ya Tuhanku, nampakkanlah (diri Engkau) kepadaku agar aku dapat melihat kepada Engkau". (Tuhan) berfirman: "Kamu sekali-kali tidak sanggup melihat-Ku, tapi lihatlah ke bukit itu, maka jika ia tetap di tempatnya (sebagai sediakala) niscaya kamu dapat melihat$\mathrm{Ku}$ ". tatkala Tuhannya menampakkan diri kepada gunung itu, dijadikannya gunung itu hancur luluh dan Musa pun jatuh pingsan. Maka setelah Musa sadar kembali, dia berkata: "Maha Suci Engkau, aku bertaubat kepada Engkau dan aku orang yang pertama-tama beriman".

Para mufasir ada yang mengartikan yang nampak oleh gunung itu ialah kebesaran dan kekuasaan Allah, dan ada pula yang menafsirkan bahwa yang nampak itu hanyalah cahaya Allah. Bagaimanapun juga nampaknya Tuhan itu bukanlah nampak makhluk, hanyalah nampak yang sesuai sifat-sifat Tuhan yang tidak dapat diukur dengan ukuran manusia.

${ }_{11}$ M. Quraish Shihab, Wawasan al-Qur'an, Tafsir Maudü'i Atas Pelbagai Persoalan Umat. Bandung: Mizan, 1996, 26. 
Jika filsafat materialis memberikan pernyataan bahwa segala sesuatu itu dianggap ada jika ia dapat dilihat, hal itu perlu untuk dipertimbangkan kembali eksistensinya, mengapa tidak, di dunia ini banyak hal yang tidak kasat mata akan tetapi keberadaanya adalah pasti, contoh aliran listrik tadi misalnya, meskipun secara kasat mata tampak bagaikan seutas kawat panjang tanpa adanya sesuatu yang mengalir atau sedang melakukan suatu proses perjalanan tekanan, namun jika ada seseorang yang memegang kabel tersebut akan terkena setrum listrik yang sangat membahayakan, untuk itu seseorang harus mempercayai keberadaan setrum tersebut, meskipun secara kasat mata tidak tampak adanya setrum. Kiranya dengan contoh inilah dapat dikatakan bahwa sesuatu yang ada tidak harus kasat mata. Bila ada seseorang yang tidak mempercayai keberadaanya setrum, ia boleh membuktikan sendiri.

3. Tadabbur dengan alam semesta

Dalam hal ini penulis akan membahas empat persoalan. Pertama, terlalu terang. Kedua, terlalu besar. Ketiga, terlalu kecil, dan kelemahan indera manusia.

Pertama, terlalu terang. Sesuatu yang ada memang tidak harus dapat dilihat, kelelawar misalnya, meskipun di tempat yang terang, ia justru tidak dapat melihat yang ada sekelilingnya. Ketidak mampuan kelelawar melihat pada siang hari tersebut disebabkan karena sesuatu yang menyiari sekitarnya terlalu terang sehingga ia menjadi tidak dapat melihat dengan baik, namun diwaktu malam yang gelap gulita, justru penglihatannya jauh lebih baik daripada siang hari.

Dengan demikian sesuatu yang ada bisa jadi tidak terlihat karena disebabkan sesuatu tersebut terlalu terang untuk dilihat. Namun di luar semua itu bukan berarti yang terlalu terang tersebut tidak ada lalu mengingkari keberadaannya. Begitu pula keberadaan Allah swt. karena sangat terangnya dengan bukti-bukti yang ada menjadi kita tidak mampu untuk menjangkaunya. Inilah kiranya keterbatasan manusia yang hanya 
memiliki pandangan bahwa sesuatu dianggap ada jika ia terlihat mata.

Perlu diketahui bahwa seseorang bisa jadi mengalami seprti kelelawar yang tidak mampu melihat dengan baik disaat ada cahaya yang begitu terang. Hal ini terjadi disaat seseorang terkena lampu tepat pada matanya sehingga ia silau dan tidak dapat melihat apa yang ada di depannya.

Kedua, terlalu besar. Keberadaan sesuatu bisa jadi tidak dapat terlihat karena sesuatu tersebut terlalu besar, karena penglihatan manusia terbatas. Berbeda halnya dengan burung elang yang mampu memandang dengan jelas mangsa yang sangat kecil dipermukaan tanah, padahal ia berada di atas awan. Mata elang bersudut pandang $300^{\circ}$ dan jika perlu mata itu mampu memperbesar ukuran suatu benda 6-8 kali lebih besar dari penampakan asal. Saat terbang di atas ketinggian 4.300 meter, elang dapat menjangkau wilayah sebesar 30.000 hektar wilayah di sekelilingnya.

Sehebat apapun jangkauan mata elang, ia tetap tidak akan mampu memandang jutaan kilo meter. Hal itu disebabkan karena keterbatasan penglihat manusia. Bisa jadi ia akan mengatakan tidak ada apa-apa jika planet jupiter berada di depannya, sungguh pandangan manusia terbatas. Contoh sederhana lagi ialah seekor semut yang berada di tengah pegunungan. Semut tersebut pasti tidak akan mengerti apa yang sebenarnya ia jadikan pijakkan, yaitu sebuah gunung besar yang tidak akan mungkin ia ketahui bahwa gungung itu ada, karena pandangannya sangat terbatas. Itulah sebabnya sesuatu itu seakan terlihat tidak ada jika ukuran sesuatu tersebut terlalu besar.

Ketiga, terlalu kecil. Kebalikan dari sesuatu yang terlalu besar sehingga seseorang menganggapnya tidak ada, adalah sesuatu yang terlalu kecil. Sekarang coba kita berfikir tentang sesuatu yang terlalu kecil (misalnya semut) yang berada di tengah kegelapan dan tidak akan mungkin terliat, mengapa 
demikian? Jawabannya cukup sederhana bahwa penglihatan kita sangat terbatas jika melihat semut di tengah kegelapan. Namun bukan berarti secara otomatis seseorang bisa mengatakan bahwa semut tersebut tidak ada! Tentu pernyataan itu kurang tepat, karena bukan semutnya yang tidak ada, melainkan pandangan manusia yang tidak mampu untuk melihatnya.

Keempat, kelemahan indera manusia. Filsafat empirisme meyakini bahwa segala sesuatu itu dianggap ada jika sesuatu tersebut dapat diindera. Namun di sisi lain, filsafat ini juga tidak dapat menjangkau seluruh lapisan pengetahuan, terbukti ketika dengan adanya nyawa. Meskipun semua orang meyakini bahwa ada nyawa di dalam tubuhnya, akan tetapi ia tidak mengerti dimana tempat nyawa itu bersemayam, apakah dikepala? Apakah dhati? Apakah diujung jari? Semuanya tidak tahu, padahal keberadaan nyawa tidak ada yang memungkiri bahkan salama hidupnya ia tidak pernah walau sekalipun melihat bentuk nyawa yang melakat ditubuhnya, namun bukan berarti walau tidak bisa di indera nyawa tersebut tidak ada, ia sungguh ada.

Lawan dari empirisme adalah rasionalisme, yaitu suatu faham yang memandang pengetahuan didapat bukan sekedar meng-indera, akan tetapi masuk akal. Jadi, tumpuan empirisme adalah kepada benda, sedangkan tumpuan rasionalisme adalah akal. ${ }^{12}$ Untuk mengukur 'wujud Tuhan', harus melalui kacamata rasionalisme, sebab Tuhan bukanlah materi.

\section{Hukum Sebab Akibat}

Para filusuf muslim menyatakan bahwa adanya Tuhan dapat diketahui melalui sebab akibat. Apa yang tampak di muka bumi ini tidaklah ada secara kebetulan, hal itu dapat terjadi pastilah memiliki sebab tertentu. Misalnya, suhu yang sangat dingin di daerah kutub itu disebabkan oleh sudut kemiringan bumi sehingga bagian-bagian tepi dari bumi itu hanya terkena sedikit sinar matahari. Begitu pula pada bagian bumi yang memiliki suhu agak panas itu pasti disebabkan oleh

${ }^{12}$ Nunu Burhanuddin, Filsafat Ilmu. Jakarta: Prenada Media, 2018, 42. 
cahaya matahari yang tepat mengenai wilayah tersebut, biasanya di daerah garis katulistiwa.

Contoh lain mengenai sebab akibat ini dapat kita jumpai di beberapa tempat, misalnya besi itu dapat memuai disebabkan karena dipanaskan dengan suhu tertentu. Oleh karena itu, bila kita mengamati jagad raya serta isinya, maka ia adalah akibat dari hal sebelumsebelumnya, dan pastilah diujung semua itu ada penyebabnya, dan penyebab terahir adalah Tuhan, Allah swt. Muhammad bin Ṣălih bin Uthaymin menyatakan bahwa budüth al-ashya' dalīl 'ala wujüd Allah (adanya sesuatu di alam raya ini sebagai bukti wujud Allah). ${ }^{13}$

\section{Pencipta Alam, Keserasiannya dan Kelemahan Pandangan Manusia}

Untuk mencapai pemahaman tentang adanya Tuhan, maka kita tidak akan dapat melihat-Nya dengan ukuran manusia, sebab indera manusia sangat terbatas, untuk itu kita harus memiliki media untuk mengetahuinya. Allah berfirman dalam al-Qur'an supaya kita memikirkan tentang kekuasaannya.

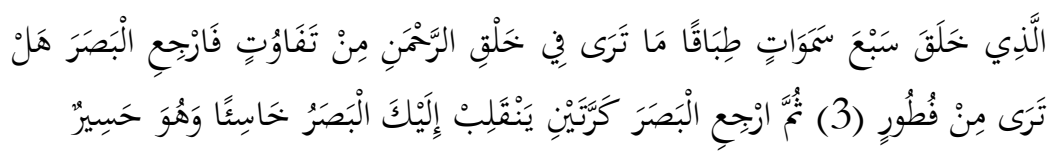

Yang telah menciptakan tujuh langit berlapis-lapis. kamu sekalikali tidak melihat pada ciptaan Tuhan yang Maha Pemurah sesuatu yang tidak seimbang. Maka lihatlah berulang-ulang, Adakah kamu lihat sesuatu yang tidak seimbang? Kemudian pandanglah sekali lagi niscaya penglihatanmu akan kembali kepadamu dengan tidak menemukan sesuatu cacat dan penglihatanmu itupun dalam keadaan payah.

Dalam ayat ini dijelaskan bahwa pandangan manusia sangat terbatas, dan Allah menguatkan lagi bahwa pandangan manusia itu memang sangat lemah. Seperti tongkat yang separuhnya dicelupkan ke

13 Muhammad bin Șạlih bin 'Uthaymin, Sharḥ al-'Aqïdah al-Safärinìyah. Al-Maktabah alShamilah al-Iṣdār Thāni, vol. 1, 33. 
dalam air, maka ia akan menjadi bengkok, namun apakah demikian sesungguhnya? Tidak! Yang sesunggguhnya terjadi ialah tongkat tersebut tetap tegak, akan tetapi pandangan manusialah yang lemah. Bintang yang kita lihat dari bumi tampak kecil bagaikan titik-titik putih yang tidak lebih dari sebesar telapak tangan manusia, akan tetapi apakah demikian kenyataannya? Tidak! Pandangan manusialah yang lemah, bintang-bintang yang tampak dari bumi bukanlah sesuatu yang kecil, bahkan salah satunya ada planet jupiter yang ukurannya 318 kali lipat dari ukuran bumi.

Kecilnya bintang-bintang tersebut karena pandangan manusia sangat lemah terbatas. Pengagungan terhadap indera manusia ini juga terjadi pada masa pertengahan, yang mana gereja pada saat itu mengalami puncak kejayaannya, yaitu semua hal, baik yang berkaitan dengan kehidupan ataupun pengetahuan alam semesta harus melalui filterisasi gereja. Faham ataupun penemuan ilmiah yang tidak sesuai dengan ajaran gerja, maka akan dimusnahkan oleh mahkamah inkuisisi.

Suatu contoh, Galileo Galilei, seorang astronom yang menyatakan bahwa pusat tata surya adalah matahari (heliosentris), bukan bumi dan bumi yang mengitari matahari, bukan sebaliknya. Penemuan Galileo ini bertentangan dengan dogma gereja yang meyakini bahwa pusat tata surya adalah bumi dan matahari mengelilingi bumi (geosentris). Dengan temuannya yang bertentangan dengan dogma gereja ini akhirnya Galileo dijatuhi hukuman seumur hidup pada tahun $1633 .{ }^{14}$

Jika seseorang merenungkan kembali ayat-ayat al-Qur'an yang menjelaskan bahwa pandangan manusia itu lemah, maka ia tidak akan lekas menyimpulkan bahwa apa yang telah mereka lihat adalah sebuah kebenaran yang hakiki. Contoh-contoh yang penulis paparkan di atas kiranya menjadi sebagian bukti bahwa pandangan itu benar-benar lemah. Hal lain masih banyak di alam raya ini yang menjelaskan demikian, misalnya saat seseorang berada ditepi pantai dan melihat dihadapannya hamparan lautan yang sangat luas, maka ia akan

\footnotetext{
${ }_{14}$ Wiwit Kurniawan, Agama, Pendidikan dan Kita: Sebuah Antologi Artikel. Bengkulu: ElMarkazi, 2017, 52-53. Dan https://nternationalkompas.com. 13 Februari 2018.
} 
menyaksikan bahwa langit dan laut itu bersatu, namun apakah demikian sebenarnya? Tentu tidak! Langit dan bumi tentu saja terpisah, dan yang menyebabkan ia bersatu adalah kelemahan pandangan manusia itu sendiri, karena sekali lagi pandangan manusia itu adalah lemah.

Posisi bumi

Di dunia ini banyak bukti yang dapat dijadikan suatu kesimpulan bahwa Tuhan itu ada. Diantaranya adalah dengan berfikir tentang jagad raya ini. Bila kita memikirkan tentang posisi bumi mislanya, kita akan menemukan suatu kesimpulan yang sangat hebat bahwa bumi pastilah diciptakan oleh perancang yang Maha Hebat. Andai kata posisi bumi bukan pada posisi yang sekarang ini, atau hanya digeser sedikit saja, maka akan menjadi sebuah hambatan yang sangat berat untuk kehidupan mahluk di dalamnya. Misalnya jika posisi bumi ditukar dengan planet yang paling dekat dengan matahari, maka niscaya segala sesuatu yang berada di dalamnya akan hangus terbakar.

Pergeseran tersebut dikarenakan jaraknya dengan matahari terlalu dekat dan dapat dikatakan mustahil ada kehidupan, karena mahluk hidup tidak akan mampu bertahan dengan suhu yang mampu melelehkan timah. Yang menjadi pertanyaan bukanlah mampu hidup atau tidaknya, akan tetapi hangus atau tidaknya, dan jawabannya adalah pasti hangus terbakar.

Oksigen

Pernahkan seseorang memikirkan bahwa sesunguhnya ia mendapatkan banyak kenikmatan sehari-hari? Dari hal-hal kecil sampai pada hal-hal yang besar! Contoh sedrhana misalnya pernahkah anda memikirkan berapa kali anda mengirup udara untuk bernafas? Berapa banyak oksigen yang anda butuhkan dalam satu hari? Berapa kali jantung anda harus memompanya? Sungguh sukar untuk mencari jawabannya! Manusia jarang sekali yang memikirkan hal demikian, karena untuk menjawabnya memang sangat sulit. Hal tersebut dikarenakan tak terhingganya kita melakukan pernafasan dalam seharimanusia memang cenderung tidak akan memikirkan sesuatu yang telah ia dapatkan dan hanya memikirkan sesuatu yang belum ia dapatkan - 
Spiritualis, vol. 4, no. 2, September 2018|171

tentu ia akan terasa ketika mengalami sakit dan membutuhkan oksigen yang banyak.

Orang tersebut baru akan berfikir, berapa banyak uang yang harus mereka keluarkan untuk membeli oksigen agar ia mampu bernafas kembali? Jika dihitung secara matematis, biaya manusia untuk kebutuhan bernafas setiap harinya mencapai Rp. 176.652.165 (seratus tujuh puluh enam juta enam ratus lima puluh dua ribu seratus enam puluh lima rupiah). ${ }^{15}$ Jika angka tersebut dikalikan dalam satu bulan, maka bisa mencapai angka 5,3 Milyar. Yang menjadi pertanyaan adalah berapa lama kita sudah hidup?

Tuhan yang menciptakan alam semesta ini telah men-design bumi dan seisinya dengan keseimbangan, manusia tidak perlu bersusahpayah untuk mencari oksigen karena telah tersedia di bumi. Oksigen yang teah Allah berikan kepada segenap mahluk hidup hakikatnya adalah supaya kita bersyukur atas nikmat yang telah diberikan-Nya, belum pernah ada cerita bahwa disuatu daerah tertentu kekurangan oksigen sehingga penduduknya mati. Secara sadar atau tidak sesungguhnya Allah-lah yang menciptakan keserasian di jagad raya ini, dengan memberikan oksigen yang sesuai dengan kebutuhan makhluk hidup.

Keterangan di atas yang menjelaskan tentang kelemahan pandangan manusia sesungguhnya memiliki hikmah yang lain. Allah menciptakannya dengan sengaja dan sesuai dengan fungsinya. Misalnya bila mata manusia diberi kekuatan pandangan seperti mata burung elang, maka yang akan terjadi adalah sebuah ketidak-nyamanan ia dalam melakukan aktifitasnya sehari-hari. Hal ini disebabkan karena ia akan melihat seorang wanita yang memakai busana yang rapi sekalipun akan tembus pandang, karena ketajaman mata elang mampu melihat sejauh $150 \mathrm{~m}$. warna yang ada dibalik celah kain yang teramat kecil dan mampu memperbesarnya hingga 12 kali lipat dari ukuran yang semestinya.

Dengan demikian, jika mata manusia diberi kekuatan pandangan bagaikan mata elang, maka bila melihat seseorang yang berpakaian menjadi trasparan. Tentunya hal ini akan mengganggu aktifitanya karena

${ }^{15}$ https://analisadaily.com, 20 Agustus 2018. 
tiap hari dipenuhi dengan kemaksiatan. Untuk itu mata manusia diciptakan oleh Tuhan bukan tanpa sebab dan tujuan, melainkan dengan ketelitian dan keseimbangan. Pencipta tersebut tidak lain adalah Allah swt. "Bukankah Kami telah memberikan kepadanya dua buah mata?" Allah telah menciptakan mata dengan ukuran yang sesuai dengan kebutuhan kita.

\section{Penciuman}

Tuhan itu bukan mahluk, apapun yang ada dalam pikiran manusia, jika ia menemukan gambaran Tuhan, maka yang dia temukan bukanlah Tuhan, tetapi ciptaan Tuhan. Itu disebabkan Tuhan itu bukanlah materi, dan manusia tidak akan mampu melihat sesuatu yang bukan materi. Jangan heran ketika seseorang membicarakan mengenai malaikat yang tidak makan dan minum serta hal-hal lain seperti yang dilakukan manusia, apakah ia tidak lapar? Apakah tidak haus? Apakah tidak mengantuk? Apakah tidak capek? Apakah tidak mengerti jika sate itu enak?. Pertanyaan-pertanyaan seperti di atas wajar bila terjadi karena manusia akan memikirkan segala sesuatu seperti dirinya dan kurang menyadari bahwa yang membutuhkan makan, minum, tidur dan lain sebagainya adalah jasad manusia yang terdiri dari daging, tulang dan organ-organ lain yang setiap hari membutuhkan asupan gizi untuk memenuhi kinerjanya. Mata membutuhkan istirahat 8 jam dalam sehari semalam, hal ini disebabkan mata adalah bagian dari tubuh manusia yang memerlukan istirahat juga. Jadi manusia itu membutuhkan kebutuhan-kebutuhan hidupnya karena ia adalah jasad.

Berbeda halnya dengan malaikat, ia tidak membutuhkan itu semua karena ia bukan jasad. Malaikat terbuat dari cahaya dan tentu saja tidak membutukan makan, minum istirahat dan sebagainya. Itulah karenanya manusia akan mengukur segala sesuatu itu dengan dirinya sendiri. Tuhan tentu saja tidak akan mampu digapai oleh manusia kecuali dengan memikirkan ciptannya.

Kadang manusia ingin memiliki sesuatu yang melebihi kebiasaanya sehingga ia akan mendapatkan pujian atau seseuatu yang berbeda dengan yang lain. Tidak jarang keinginan yang terlalu itu justru akan menjadikan manusia menjadi tidak akan nyaman dalam 
kehidupannya. Contoh konkrit dalam menjelaskan keberadaan Tuhan adalah karena Ia menciptakan manusia dengan sempurna dan dengan anggota badan sesuai dengan fungsi yang dibutuhkan oleh manusia. Misalnya bila manusia menginginkan penciumannaya melebihi dari ukuran normal, maka ia akan melihat bahwa yang memiliki penciuman sangat tajam adalah anjing.

Bila manusia memiliki penciuman yang seperti itu, maka yang akan terjadi adalah hal yang tak akan pernah terbayangkan, yaitu manusia akan mencium bau kentut seseorang dengan jarak berkilo-kilo meter, itu berarti kita akan selalu mencium bau kentut penduduk se desa jika kita memiliki penciuman setajam anjing. Begitu juga dengan hal-hal lain yang menyatu dengan kita misalnya bau badan, bau kaos kaki dan sebagianya yang kadang kala kita merasa tidak nyaman atau bahkan malu saat ada orang lain yang mencium bau tersebut. Lebih parah lagi jika penciuman kita setajam penciuman anjing dan tentu saja bau yang tidak seberapa akan menjadi berkali-kali lipat tajamnya, dari yang sewajarnya, apalagi dengan bau limbah pabrik, limbah perkotaan dan sebaginya yang kadang membuat seseorang mual bahkan muntahmuntah. Itu berarti Tuhan yang menciptakan penciuman kita dengan ukuran ketajaman yang sangat teliti dan tepat. ${ }^{16}$

\section{Pendengaran}

Makluk hidup di darat yang memiliki pendengaran paling peka adalah anjing dan jangkrik. Jika pendengaran manusia sepeka anjing dan jangkrik, maka bisa jadi ia tidak akan bisa tidur nyenyak. Sebab, suara nyamuk bisa jadi seperti knalpot motor, suara semut berjalan atau hewan-hewan kecil lainnya akan sangat mengganggu pendengarannya. Oleh sebab itu, Tuhan memberikan manusia pendengaran yang sesuai dengan kebutuhannya. Sangat tepat kiranya apabila manusia diberi label oleh Tuhan bahwa ia adalah ciptaan yang paling sempurna (absan altaqwim). Bukan hanya diberi akal, akan tetapi diberi indera yang sesuai dengan kebutuhannya.

${ }^{16}$ Harun Yahya, al-Qur'an Menjawab Tantangan Zaman, menit 30. 
Spiritualis, vol. 4, no. 2, September 2018|174

\section{Kesimpulan}

Kesimpulan artikel ini adalah keyakinan bertuhan dapat dibenarkan kalau lulus uji. Batu uji ketuhanan itu adalah: Pertama, kekal. Disebut sebagai Tuhan kalau dia kekal. Jika pernah mati, berarti dia makhluk. Kedua, monotheis. Jika Tuhan ganda, maka akan terjadi kekacauan sistem, karena ada dua kekuasaan. Ketiga, tanఇịh (bersih dari unsure-unsur makhluk) serta bebas relativitas ruang dan waktu. Sedangkan wujud Tuhan dapat diketahui melalui rasionalisasi terhadap jagad raya, seperti posisi bumi di dalam sistem tata surya, ketersediaan oksigen di alam raya serta penciptaan terbaik dalam tubuh manusia berdasarkan kebutuhan hidupnya. Tadabbur ini dilakukan untuk membuktikan wujud Tuhan melalui rasionalisasi bukan empirisasi. 
Spiritualis, vol. 4, no. 2, September 2018|175

\section{DAFTAR PUSTAKA}

'Uthaymin, Muhammad bin Șăalih. Sharḥ al-'Aqìdah al-Safärinìyah. AlMaktabah al-Shamilah al-Ișdār Thāní.

Burhanuddin, Nunu. Filsafat Ilmu. Jakarta: Prenada Media, 2018.

Departemen Agama Republik Indonesia, al-Qur'an dan Terjemahnya. Surabaya: Pustaka Assalam, 2010.

Kurniawan, Wiwit. Agama, Pendidikan dan Kita: Sebuah Antologi Artikel. Bengkulu: El-Markazi, 2017.

Lembaga Alkitab Indonesia, Alkitab Terjemahan Baru. Jakarta: LAI, 1994.

Mahmudin, Menemukan Kebenaran Islam. Yogyakarta: Gava Media, 2006.

Ramli, Andi Mu'awiyah. Peta Pemikiran Karl Marx: Materialisme Dialektis dan Materialisme Historis. Yogyakarta: LKiS, 2000.

Shihab, M. Quraish. Wawasan al-Qur'an, Tafsir Maudüi Atas Pelbagai Persoalan Umat. Bandung: Mizan, 1996. 